\title{
PLANKTON RICHNESS AND ABUNDANCE IN SEVERAL DIFFERENT HYDROLOGICAL SITUATIONS IN LAKES LATERAL TO A RIVER: A CASE STUDY IN THE MOUTH ZONE OF A TRIBUTARY INTO A TROPICAL RESERVOIR*
}

\author{
Raoul Henry ${ }^{l^{*}}$, Eliana Aparecida Panarelli ${ }^{2}$, Silvia Maria Caglierani Casanova ${ }^{3}$, Danielli Cristina \\ Granado $^{4}$, Rafael Campanelli Mortari ${ }^{5}$ \& Juliana Abra ${ }^{1}$ \\ ${ }^{1}$ State University of São Paulo (UNESP), Institute of Biosciences, Department of Zoology, Campus of Botucatu, São Paulo State, Brazil, CEP:18618-970. \\ ${ }^{2}$ State University of Minas Gerais (UEMG), Campus of Frutal, Minas Gerais State, Brazil, 38200-000. \\ ${ }^{3}$ Hidrologica Environmental Advisory and Consultancy Services, Botucatu, São Paulo State, Brazil, 18610-307. \\ ${ }^{4}$ State University of São Paulo (UNESP), Experimental Campus of Rosana, São Paulo State, Brazil, 19274-000. \\ ${ }^{5}$ Paulista University (UNIP), Campus of Bauru, São Paulo State, Brazil, 17098-490. \\ E-mails: rhenry@ibb.unesp.br, epanarelli@ig.com.br,casanova@hidrologicaconsultoria.com.br,danielli@rosana.unesp.br, rafamortari@hotmail.com, \\ juabra@gmail.com
}

\begin{abstract}
A descriptive analysis of the responses of plankton from lakes lateral to a river in its mouth zone into a tropical reservoir to water level variations is presented. Three situations were reported: 1) a comparison of species richness and diversity and of algae population abundance in prolonged drought and in periods of connection of lakes to the river, 2) the spatial distribution of abundance and richness of Rotifera species in four isolated water bodies formed by fragmentation of a lateral lake during a period of prolonged drought and in the same areas during a period of integrity as an ecosystem, 3) the variability of total zooplankton and Cladocera densities at the end of the isolation period of a lateral lake and after the recovery of connection with the river and in a year of continuous connection with the lotic ecosystem. Various idiosyncrasies were observed in connected lateral lakes, like the surface hydrologic connectivity, a primary factor in species richness modifications and a secondary controlling factor of plankton abundance. Underground hydrologic connectivity, through the river $\rightarrow$ lake water flux during the high-water period and lake $\rightarrow$ river during drought period, appears to have an important role in richness and abundance variations of planktonic populations in the lake isolated from the river.
\end{abstract}

Keywords: Zooplankton; phytoplankton; water level; connectivity; aquatic ecosystems.

\section{RESUMO}

RIQUEZA E ABUNDÃNCIA DO PLÂNCTON EM DIFERENTES SITUAÇÕES HIDROLÓGICAS EM LAGOAS LATERAIS A UM RIO: UM ESTUDO DE CASO NA ZONA DE DESEMBOCADURA DE UM TRIBUTÁRIO EM UM RESERVATÓRIO TROPICAL. Uma análise descritiva das respostas do plâncton de lagoas laterais a um rio na zona de sua desembocadura em um reservatório tropical, às variações do nível de água é apresentada. Três situações foram relatadas: 1) comparação da riqueza e diversidade de espécies e da abundância das populações de algas em períodos de seca prolongada e de conexão das lagoas com o rio; 2) distribuição espacial da abundância e riqueza de espécies de Rotifera em quatro corpos de água isolados formados por fragmentação de lagoa lateral durante período de seca prolongada e nas mesmas áreas em período de sua integridade como ecossistema; 3) variabilidade na densidade total do zooplâncton e de organismos de Cladocera em final de período de isolamento das lagoas laterais e após restauração de sua ligação com o rio e, em ano de associação continua com o curso de água. Várias idiossincrasias foram observadas nas lagoas laterais conectadas, sendo a conectividade hidrológica de superfície, fator primordial nas modificações 
da riqueza de espécies e, fator controlador secundário da abundância do plâncton. A conectividade hidrológica subterrânea, através do fluxo de água rio $\rightarrow$ lagoa no período de cheia e lagoa $\rightarrow$ rio no período de estiagem, parece ter um papel fundamental na riqueza e abundância das populações planctônicas em lagoa isolada do rio.

Palavras-chave: Zooplâncton; fitoplâncton; nível de água; conectividade; ecossistemas aquáticos.

\section{INTRODUCTION}

In inundation plains of great rivers, the controlling factor in biological communities and in ecological processes in lateral aquatic environments is the flood pulse (Junk et al. 1989). Hydrologic level variability of rivers during the year promotes a lateral influx of water in multiple pulses of short duration, as in the Mogi-Guaçu plain, São Paulo, Brazil (Krusche \& Mozeto 1999) and in the Upper Paraná River floodplain (Lansac-Tôha et al. 2009, Roberto et al. 2009), or in uni-modal pulse, as in the Pantanal Matogrossense, Brazil (Hamilton et al. 1998). These temporary or long duration connections lead to biota, dissolved and particulate material, and nutrient exchanges, shaping the so-called connectivity between aquatic ecosystems (Ward et al. 1999, Tockner et al. 2000). Lateral water flux from river to lateral lakes is an example of a process of temporary or recurrent character that connects different ecosystems and that was defined recently as an ecosystem linkage (Lamberti et al. 2010). In fact, aquatic floodplain ecosystems rarely act independently from one another; surface and underground connections facilitate the exchange of nutrients and particulate matter, mutually influencing the ecosystems involved. Lateral connectivity is an important measure of the conservation of the integrity of temporary aquatic environments and their macroinvertebrate fauna in an arid zone of a river (Sheldon $e t$ al. 2002). Hydrologic connectivity can be considered as a disturbance factor that, at an intermediate level, may determine a biodiversity maximum in aquatic environments lateral to a river (Bornette et al. 1998, Ward et al. 1999). The effects on lentic environments far from the river are only effective when longduration high-water pulses occur. It is also important to consider the period when the pulses occur during the year (Van den Brinck et al. 1994).

Seasonal inundation is a stimulating factor of phytoplankton growth in a lake of the Amazonian floodplain (Huszar \& Reynolds 1997). In a comparative study of phytoplankton dynamics in two inundation lakes with distinct hydrological connectivity with the Acre River (Amazonas), Philips et al. (2008) showed that, in the lake permanently connected with the river, the algae density was low, and the same was observed for the low-connectivity lake when connected with the river. However, after the isolation from the river and a reduction in turbidity, phytoplankton density increased by one order of magnitude and, at the same time, total $\mathrm{N}$ and $\mathrm{P}$ concentrations decreased, and $\mathrm{O}_{2}$ increased. In the Pantanal floodplain, the inundation pulse leads to a dominance of nanoplanktonic algae species (Cryptophyceae and Euglenophyceae classes), more resistant to and tolerant of heterotrophic conditions (Oliveira \& Calheiros 2000). At the inundation plain of High Paraná (Brazil), the abundance and richness of the Rotifera species were related to hydrologic connectivity (Aoyagui \& Bonecker 2004). A higher number of taxa were recorded in rivers and a lower one in isolated lakes, in contrast to a higher abundance in connected lakes, followed by isolated lakes and rivers. At the inundation plain of Middle Paraná (Argentina), José de Paggi \& Paggi (2007) showed that zooplankton abundance and species richness increased in a crescent sequence of distinct environments from the main channel of the river, followed by secondary channels of the river, lakes connected directly with the rivers and, finally lakes connected indirectly with the river. Spatial heterogeneity in the interior of each of these environments and water residence time of each are factors increasing the two mentioned attributes of assembly.

In Brazil, especially in the southern region, the great rivers were modified in a cascade sequence of reservoirs that cause a series of impacts on fish fauna (Agostinho et al. 2008) and on phytoplankton distribution (Nogueira et al. 2010). Therefore, the lateral inundation pulses disappeared completely or were greatly attenuated as a result of water masses stored in each reservoir. Marginal lakes in the mouth zone of tributaries into reservoirs are relict sites that, however, are not subject, as inundation plains are, to temporary and recurrent processes of connection and 
isolation due to water pulses by rivers. In the majority of cases, they are environments permanently connected with rivers presenting high but variable connectivity as a result of hydrologic levels of tributaries and of the operating system of reservoirs. Thus, lateral lakes in the mouth zone of the tributaries are distinct from lacustrine environments of floodplains in function and structure.

Considering that plankton has a short generation time and can be used as a good indicator of the characteristics of the inhabited environments, the ecological attributes (species richness and abundance) of this assembly were examined in lakes lateral to a great river in its mouth zone into a reservoir. The aim of this paper was to respond: 1) how plankton (algae, rotifers, cladocerans, and copepods) of lateral lakes is affected by the annual variation of the hydrologic level of the river, 2) how variable duration periods of isolation of lakes from the river change the plankton community attributes, and 3) how a prolonged drought episode is determining in the characteristics of plankton community.

\section{MATERIAL AND METHODS}

\section{THE STUDY AREA}

The study site is the transition area of the Paranapanema River - Jurumirim Reservoir (São Paulo, Brazil). This watercourse is the main tributary of the reservoir and in the mouth zone where some lateral lakes are linked to the lotic ecosystem (Figure 1). Some lateral lacustrine environments were selected for the study: two (Coqueiral and Camargo Lakes) present a connection with the river, while one (Cavalos Lake) is isolated from the river.
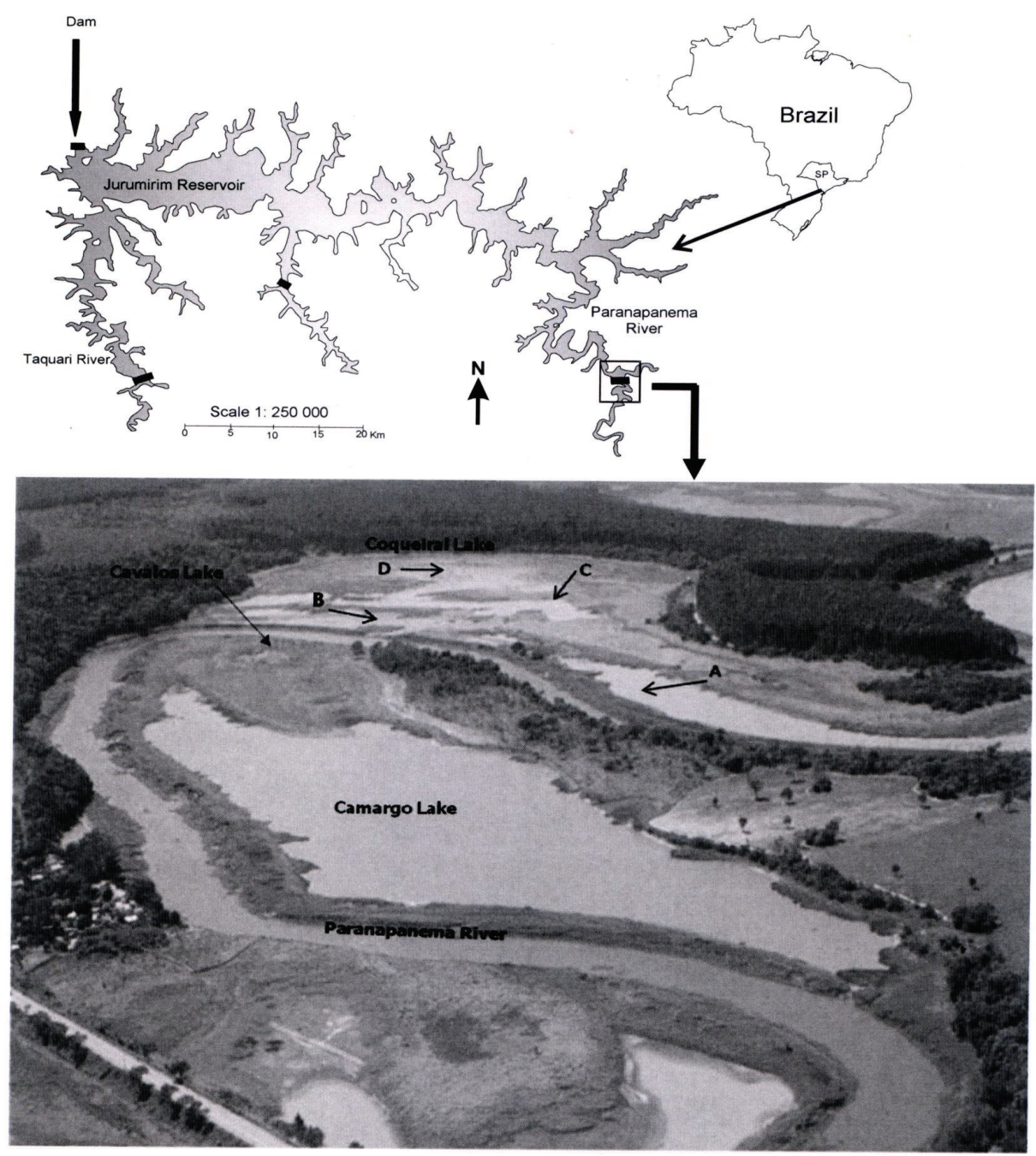

Figure 1. Study area: the mouth zone of the Paranapanema River at Jurumirim Reservoir (São Paulo, Brazil). The letters A, B, C, and D indicate the sites of the fragments in Coqueiral Lake during the prolonged drought period (Photography from May 23, 2000). 
In the mouth zone of the tributary into the artificial lake, the Paranapanema River presents a pronounced reduction in current velocity (Casanova \& Henry 2004, Henry et al. 2006a). As a consequence, the sedimentation of material from the watershed (area: $17,800 \mathrm{~km}^{2}$ ) is significant, if compared with its deposition in the longitudinal axis upstream (riverine zone) $\rightarrow$ downstream (dam zone) of the reservoir (Henry \& Maricato 1996). The annual load of sediments introduced into the reservoir corresponds to around 150,000 tons (409 ton.day ${ }^{-1}$ ), however the efficiency of sediment deposition in the two marginal lakes (Coqueiral and Camargo) does not exceed 5\% of the conveyed total (Henry 2009).
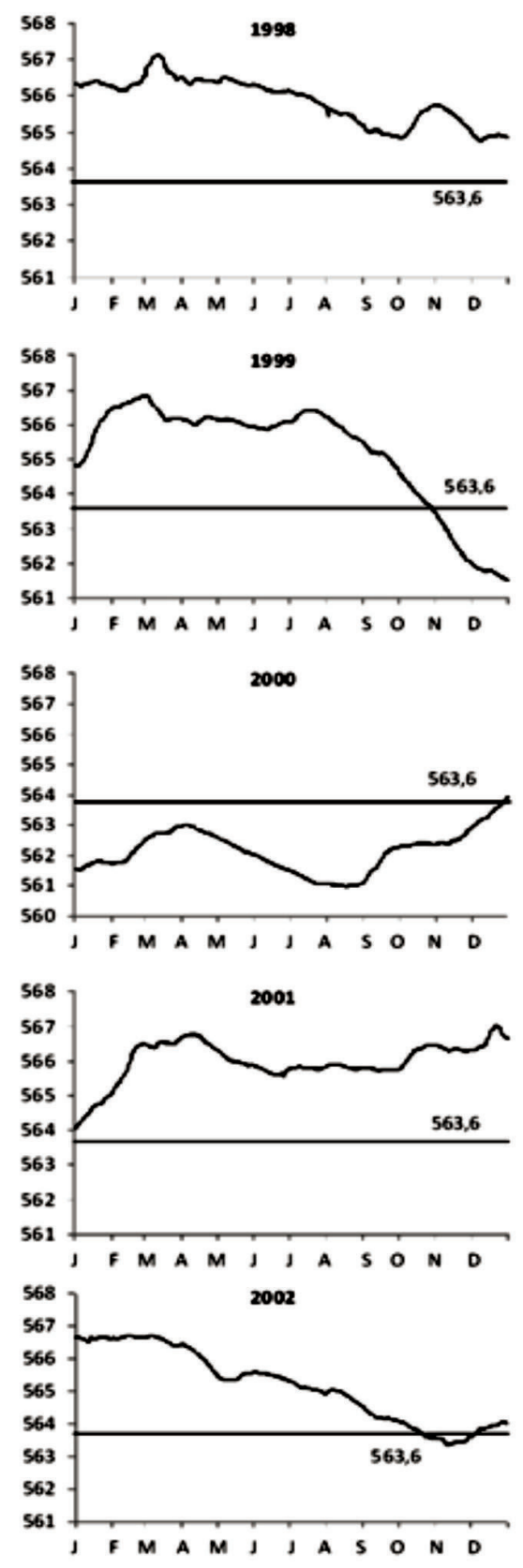

Due to the characteristics of the studied site, connectivity, defined as a "composite" of frequency and duration of lateral inundation by the river and water renewal in marginal lakes during the high and low water periods (Galat et al. 1997), is apparently permanent. Thus, the exchange of dissolved and particulate organic and inorganic matter and biota between the ecosystems is potentially great. The duration of the lacustrine environments in limnophase, disconnected from the river, was insignificant in the majority of the ten years of survey (Figure 2).

Except during a prolonged period (from October 1999 to the end of December 2000) and three short periods (2002, 2006 and 2007, Figure 2), the lakes
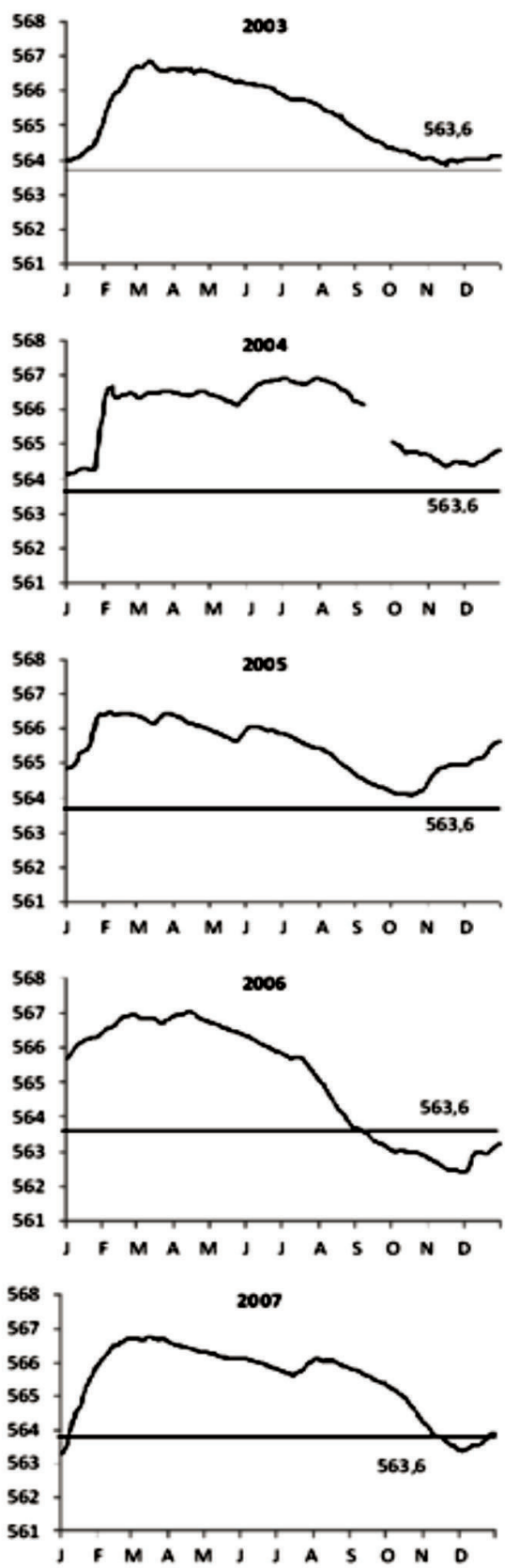

Figure 2. Daily hydrometric levels of ten-year readings (from January 01, 1998 to December 31, 2007). The solid horizontal line at 563.6m water level reproduces the hydrometric level of a frontier between overflow (above) and disconnection (below) of lateral lakes with the river. 
remain in potamophase, as Neiff (1999) called it in studies in the floodplain of Middle Paraná (Argentina). The fluvial connectivity coefficient (a ratio of number of inundation days to the number of isolation days of lakes in relation to the river, after Neiff \& Poi de Neiff 2003) was 10.4, 2.0, and 12.5 for the years 2002, 2006, and 2007, respectively. As can be concluded, the behavior of marginal lakes and the Paranapanema River is not similar to that of inundation plains, since the fluvial connectivity is very high as compared to the Floodplain of Middle (Neiff 1999, Neiff \& Poi de Neiff 2003) and High Paraná (Bonecker et al. 2009). Thus, the elasticity coefficient, defined as a ratio of the area covered by the lateral plain during the maxima of inundation by the corresponding area during the drought period, is low (1.07 and 2.02 for the Camargo and Coqueiral Lakes, respectively, according to Henry (2005)). This means that the marginal lentic environments present an apparent hydrologic stability as a result of highly attenuated water pulses of river in this region. This behavior, differently from the inundation plains, is due to the great mass of water stored in the Jurumirim Reservoir, which functions as an "absorber" or "buffer" system of the pulses of the main tributaries (Henry 2005).

Despite this fact, the annual variation of the water level of the Paranapanema River in the study site is very similar to the unique modal pulse at Pantanal Matogrossense (Hamilton et al. 1998) and is very distinct from the characteristics of the Mogi-Guaçu River, which presented multiple short pulses during the year of study (Krusche \& Mozetto 1999). As can be seen in Figure 2, high water levels of the Paranapanema River were recorded in March at the end of rainy season (Figure 3). During the majority of the year, levels were almost constant until August, when they presented a reduction and attained the lowest levels in November/December (Figure 2). Approximately one to two months after the beginning of the rainy season (in September/October, during most of the ten years of measurements, see Figure 3), an increase in the water level of the Paranapanema River was observed, newly connecting the river to the lakes in the years $(2002,2006$, and 2007) of short (32 and 27 days in 2002 and 2007, respectively) and long duration of limnophase (121 days in 2006). Extreme duration limnophase (from October 1999 to December 2000) was an anomalous condition in this study. In this period, an extraordinary drought occurred, and one of the lakes (Coqueiral) "fragmented" into four small water bodies isolated from one another as a result of bottom topography (Henry 2005, Nadai \& Henry 2009). The other lake (Camargo Lake) experienced a drastic reduction in volume, but a small diminution in surface area (Henry 2005). The third lake (Cavalos) was extinct in June 2000 (Panarelli et al. 2008) due to water evaporation in that year of prolonged drought and also due to underground water flux from lake to river, as shown by another study (Carmo 2007).

Water level variations during the ten years of measurement are values of stages recorded at Jurumirim dam and, according to Pompeo et al. (1999), they followed the same pattern of modifications at the mouth region of the Paranapanema River into the reservoir. Changes in water levels of the river were an opportunity to test their effects on planktonic assemblies of lacustrine environments in several hydrologic situations:

\section{Situation 1}

A comparison of species richness and diversity and abundance of phytoplankton was conducted during the extreme drought period and during a hydrologic year when lateral lentic environments presented permanent connectivity.

\section{Situation 2}

Modifications in spatial and temporal distribution of Rotifera assembly were determined in Coqueiral Lake during the "fragmentation" period and during a hydrologic year when the water body maintained its unity as an ecosystem.

\section{Situation 3}

A detailed verification of monthly variations in Camargo Lake in density of total zooplankton (Rotifera, Cladocera, and Copepoda) and also of only Cladocera organisms was carried out, comparing two distinct periods: the end of the prolonged drought and the beginning of inundation periods, and a hydrologic period of maintenance of connectivity between marginal lakes (in this case, Camargo Lake) and the Paranapanema River. Also, the importance curves 

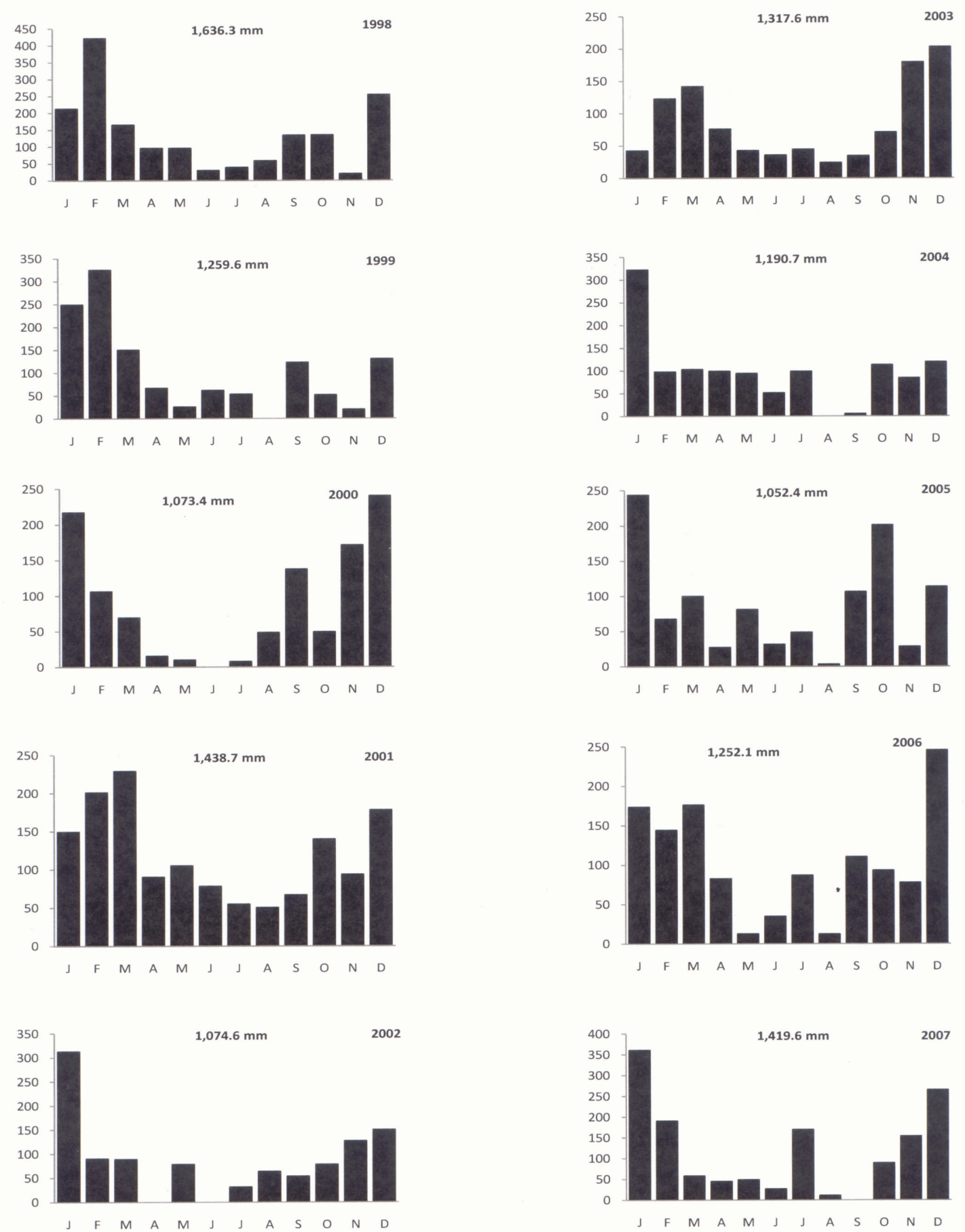

Figure 3. Monthly rainfall (mm) variations from January 1998 to December 2007 at Angatuba (São Paulo) and total annual precipitation (Note that the data scale on the vertical axis differs in the ten years).

of Cladocera populations were compared in order to show the assembly organizations at: a) the end of an extreme drought period and seven months after the recovery of connectivity of Paranapanema River with Camargo Lake, and b) in high and low water months in potamophase and limnophase of Camargo Lake, respectively, in another hydrologic year.

\section{PLANKTON SAMPLING}

\section{Situation 1}

In the extreme drought period, phytoplankton was sampled with a Van Dorn bottle in each of four months (November 1999, February, May, and August 2000) at the surface of the pelagic zone of 
the three lacustrine lakes and of the Paranapanema River. Later, in August and November 2004, as well as in February, April, and June 2005 (a hydrologic year without disconnection of the lakes from the river), the same sampling procedure was repeated in the four sites. Samples were preserved in acetic lugol, and in laboratory the algae species populations were amounted using an inverted microscope (400x magnification) through the Utermohl's method (1958). Volume in sedimentation chamber ranged from 2 to $20 \mathrm{~mL}$, in a dependence of algae and detritus concentrations in the sample and, sedimentation time before counting corresponded to 3 hours for each $\mathrm{cm}$ of height chamber (Margalef 1983). At least 100 individuals of the more abundant species were counted in each sample or alternatively the field number for counting was determined by the rarefaction curve. Algae was classified according to Round (1971) for Chlorophyceae and Zygnemaphyceae, Simonsen (1979) for Bacillariophyceae, Komarek \& Anagnostidis $(1998,2005)$ and Anagnostidis \& Komarek (1988) for Cyanophyceae and, Bourrelly $(1981,1985)$ for the others. Densities were expressed in ind. $\mathrm{mL}^{-1}$ (APHA 1995) and diversity index (bits. ind $^{-1}$ ) was computed according to the Shannon-Wiener formula (Krebs 1972). Taxa richness represents the number of species in the sample.

\section{Situation 2}

Surface water samples were collected every three months (April, July, and October 2000, February and May 2001) during and immediately after the prolonged drought episode in 12 sites in Coqueiral Lake (three sites each in "fragments" A and C, four sites in "fragment" B and two sites in "fragment" D, see Figure 1). Fragments correspond to remaining water bodies of Coqueiral Lake after the great reduction on surface water level during the drought episode. A volume ranging from 50 to $120 \mathrm{~L}$ of water were filtered in a $50 \mu \mathrm{m}$ mesh net, depending on the time of year and the depth at each site.

Later, in the same areas corresponding to "fragments" A, B, C, and D (at three sites each) water samples were collected through vertical drawing of a $50 \mu \mathrm{m}$ mesh net. A minimum of $150 \mathrm{~L}$ of water was filtered; in sites with low depth, the same procedure was repeated when necessary in order to obtain this minimum volume. When the selected sampling sites presented a depth $<1 \mathrm{~m}$, especially in the drought period, surface water (150L) was collected with a bucket. Samplings were conducted every three months in 2006 (January, April, July, and October), a year when there was a short-duration disconnection of the lake from the Paranapanema River (Figure 2).

Analysis of the assembly was restricted to Rotifera organisms. Individuals were counted in 1-mL samples using a Sedgwick-Rafter chamber. Species were identified according to Koste (1978), Pontin (1978), Segers (1995), Nogrady \& Segers (2002). Taxa richness is the number of species observed in the chamber. Densities of the populations were expressed in number of individuals. $\mathrm{m}^{-3}$.

\section{Situation 3}

In the second half of the extraordinary drought episode (July to December 2000) and in the first seven months after the lateral inundation of Camargo Lake by waters of the Paranapanema River (from January to July 2001), surface water samples were filtered monthly with a pump in a $50 \mu \mathrm{m}$ mesh net. Zooplankton was also collected in the water column from $0.5 \mathrm{~m}$ above bottom up to surface through vertical drawing of a 50- $\mu \mathrm{m}$ mesh net monthly, due to the low depths of the lake from August 2006 to March 2007, a year when there was a disconnection of the lake from the river of four months (from September 2006 to January 2007). After the collection, zooplankton was preserved in $4 \%$ formaldehyde.

Zooplankton species were identified using the specialized literature (Edmondson 1959, Brandlova et al. 1972, Rocha \& Matsumura-Tundisi 1976, Koste 1978, Pontin 1978, Reid 1985, Korovchinsky 1992, Segers 1995, Elmoor-Loureiro 1997, Nogrady \& Segers 2002).

In the monthly collected samples, Copepoda and Cladocera organisms were counted in $5 \mathrm{~mL}$ sub-samples in an acrylic chamber using a stereomicroscope, and Rotifera in $1 \mathrm{~mL}$ sub-samples in a Sedgwick-Rafter chamber using a microscope. Zooplankton total density was expressed by individuals. $\mathrm{m}^{-3}$ and refers to densities of Copepoda, Cladocera, and Rotifera.

Importance curves were prepared using data of population densities of Cladocera species recorded in samples of December 2000 (end of the drought period), July 2001 (seven months after the lateral 
influx of water by the river), April 2006 (high-water period) and November 2006 (low water period in the lake, disconnected from the river), in order to compare the structures of the assemblies.

\section{RESULTS}

\section{SITUATION 1}

During the prolonged drought, the highest total algae richness of the four sampling periods (from November 1999 to August 2000) was found in the Paranapanema River (94 taxa), followed by Cavalos (73 taxa), Coqueiral (35 taxa), and Camargo Lakes (33 taxa) (Henry et al. 2006b). The highest number of exclusive taxa was observed in Paranapanema River (54 taxa), followed by Cavalos (14 taxa), Coqueiral (9 taxa), and Camargo Lakes (1 taxon) (Henry et al. 2006b). Higher species richness was recorded in Paranapanema River and next, in the Cavalos Lake (except in November 1999) (Figure 4). A continuous increase in phytoplankton abundance was evidenced in Cavalos Lake with the progress of drought effects
(Figure 4). Except in November 1999, a similar trend was seen for Camargo Lake. In Coqueiral Lake, a continuous reduction in phytoplankton abundance was observed in the first three initial periods of sampling (November 1999, February, and May, 2000), one, four, and seven months after the beginning of the drought, respectively, and, an increase at the end of the period (August 2000). Three algae species of the phytoplankton assembly were dominant (abundance $>50 \%$ of total density): Chlamydomonas sp., Chroomonas sp. and Cryptomonas brasiliensis (Henry et al. 2006b). These species account for more than $50 \%$ of relative abundance in Coqueiral and Camargo Lakes in the four sampling periods and, in the Paranapanema River, they attained $92.5 \%$ of total density in February 2000. In relation to species diversity, an increase in the values was recorded in the three successive periods after February 2000 in the Paranapanema River. A diminution and a trend to reduction of diversity were evidenced in the Camargo and Coqueiral Lakes, respectively (Figure 4).
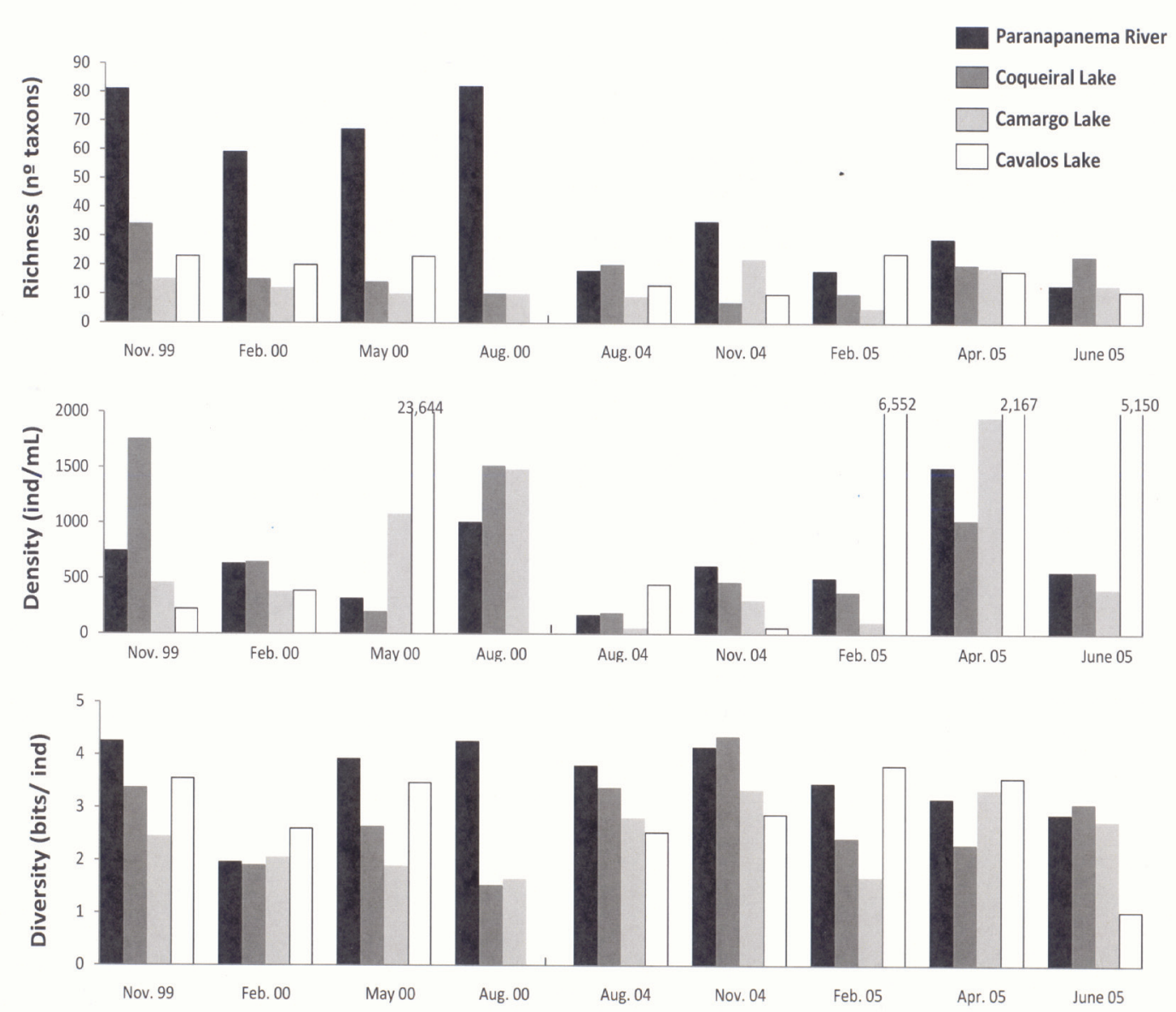

Figure 4. Species richness and diversity and density of phytoplankton at three lateral lakes (Coqueiral, Camargo and Cavalos) and at the Paranapanema River during the prolonged drought period (from November 1999 to August 2000) and the hydrologic connectivity (from August 2004 to June 2005). 
In a hydrologic year (August 2004 to June 2005) without disconnection of lateral lakes (Camargo and Coqueiral) from the river, the algae taxa richness in the Paranapanema River was around $1 / 4$ of the number of species recorded in the prolonged drought period (Figure 4). Except in Cavalos Lake, whose taxa richness was higher, the number of algae species in the other lentic environments was similar in the hydrologic period without disconnection from the river (Figure 4). In the three lacustrine environments, only one alga species (Cryptomonas brasiliensis) was constant, while in the Paranapanema River, this species and Closteriopsis acicularis were present in all the samples (Granado et al. 2009). Closteriopsis acicularis and Cryptomonas brasiliensis were dominant algae species in the Paranapanema River in April 2004 and in the other sampling periods. C. brasiliensis was predominant in November 2004, February, April, and June 2005 in Coqueiral Lake, as well as in August 2004 in Cavalos Lake. In this lentic environment, Chroococus minutus was dominant in June 2005. The highest algae densities were observed in the four environments in April 2005 (Figure 4). A great abundance of algae populations was maintained in the successive sampling periods in Cavalos Lake, an isolated environment from the river (Figure 4). From November 2004 on, the algae species diversity in Paranapanema River showed a trend to a reduction (Figure 4). An oscillation on the values of algae diversity was an evident pattern in the phytoplankton assembly in the three lacustrine environments (Figure 4).

\section{SITUATION 2}

During the first study period (from April 2000 to May 2001), 54 Rotifera taxa were recorded, while in the second (from January to October 2006), the maximum richness attained was 91 taxa, because sampling increased from three (in 2000 and 2001) to twelve (in 2006) sites. Constancy indexes and occurrence of each taxon in each site of the four "fragments" were presented in Nadai \& Henry (2009) and Abra (2008), respectively.

At the end of the drought period, the highest densities of Rotifera were recorded in "fragments" C (in April and July 2000) and D (October 2000), far away from the connection with the Paranapanema River (Figure 5a). In a drought episode, the lowest densities of Rotifera were observed in sites of "fragment" B, near the river. After the lateral inundation of Coqueiral Lake by the Paranapanema River, high abundance of Rotifera was found in February 2001 in "fragment" B. Five months after the reconnection of the lacustrine environment with the lotic ecosystem, Rotifera densities in the three areas corresponding to "fragments" A, C, and D, farther in relation to the Paranapanema River, presented values which were approximately similar (Figure 5a). A higher number of Rotifera species occurred two months after the lateral influx of water into the lake, in the four areas corresponding to "fragments" (Figure $5 b)$, while the lowest richnesses were evidenced in July 2000, six months before the end of the extraordinary drought period.

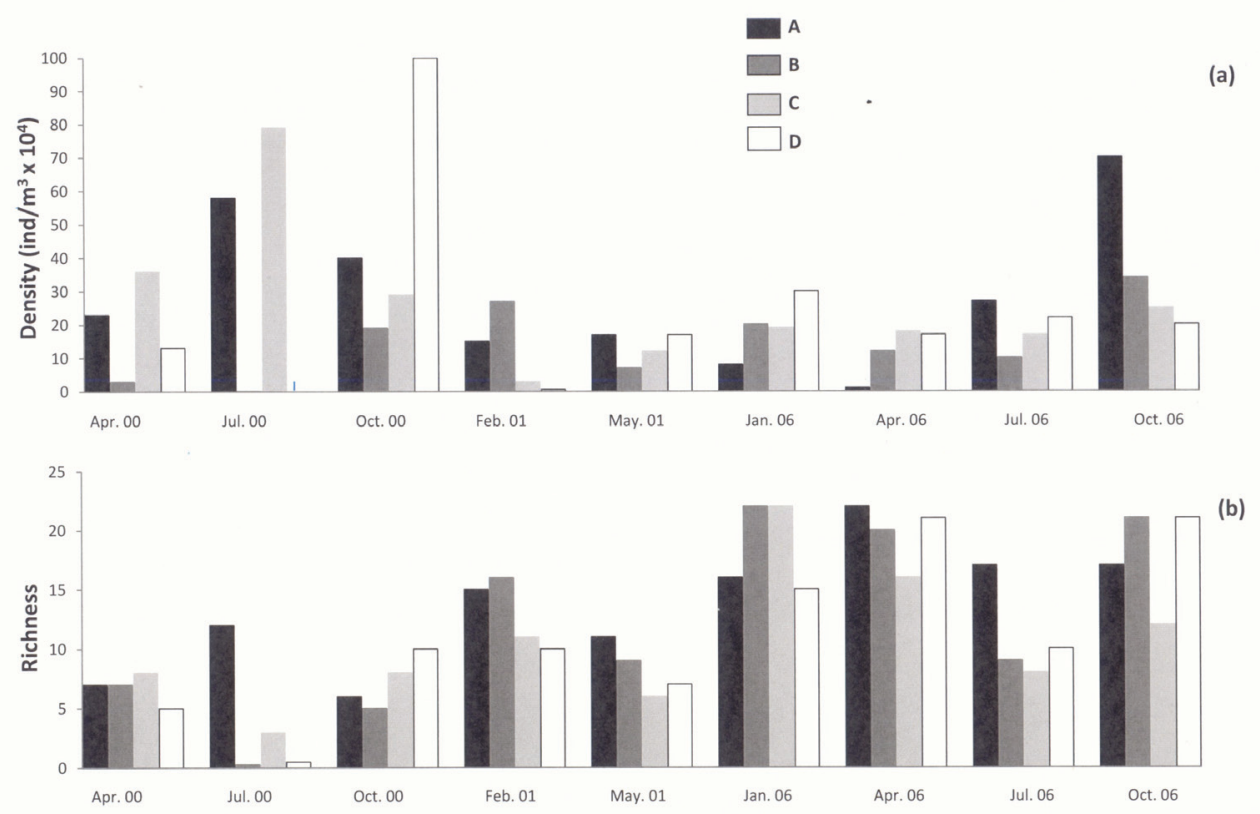

Figure 5. Total density (a) and species richness (b) of Rotifera in the four fragments/areas (A, B, C, and D) of Coqueiral Lake in (April, July and October 2000) and after (February and May 2001) the prolonged drought period and during the hydrologic year of 2006. 
In the first three sampling periods of the hydrologic year 2006, Rotifera densities were higher in the area corresponding to "fragment" D, far away from connection with the river, and were followed by the densities in $\mathrm{C}$ and $\mathrm{A}$, areas near the river (Figure 5a). The highest Rotifera density was recorded in area A in October, at the beginning of a temporary disconnection of Coqueiral Lake from the Paranapanema River (Figure 5a). No great variations in taxa richness of Rotifera were observed comparing the four areas during 2006 (Figure 5b). The lowest mean richness (11 taxa) of the four different areas was found in July, when compared with the means of January (19 taxa), April (20 taxa), and October (18 taxa) (Figure 5b).

\section{SITUATION 3}

Continuous reduction in the volume of Camargo Lake in the period from July to December 2000 (the end of the extraordinary drought episode) produced an increase in total density of zooplankton and a "peak" in abundance was attained in December (Figure 6a). Elevation in the water level of the Paranapanema River at the end of December 2000 (Figure 2) promoted a lateral inundation of Camargo Lake, continuously increasing the lake volume and maximum value occurred in April 2001 (Figure 6a). This effect produced a drastic reduction in density of zooplankton assembly, whose lowest value was observed in April (Figure 6a). A small diminution in the volume of Camargo Lake (from May to July 2001) led to an increment in zooplankton density (Figure 6a). The highest densities of Cladocera were recorded when the values of volume of Camargo Lake were the lowest, at the end of the extreme drought period (Figure 6b). Two "peaks" in abundance were observed during the end of this episode: one in April and the other in December 2000 (Figure 6c). During the recovery of connectivity of the lake with the river, an accentuated reduction in densities of Cladocera populations was observed at the same time as an increase in volume of the lacustrine environment (Figure 6b).
In the other studied period, Camargo Lake presented maximum volume in May 2006, maintaining high levels of water up to July, and after that, the water level decreased and a minimum value was recorded in November (Figure 6c). An increase in the volume of Camargo Lake occurred from December 2006 to February 2007 (Figure 6c), after an elevation of the water level of the Paranapanema River (Figure 2). An increment in total zooplankton densities was observed from April to July 2006, and after that, a reduction in abundance was recorded, with the lowest values found in November. Density increasing newly with an increment in volume of the Camargo Lake was noticed from December 2006 on. In relation to Cladocera densities, an increase was observed after the maximum volume of Camargo Lake (Figure 6d). Diminution in volume was followed by a reduction in densities. Recovery of lake volume (from November 2006 to February 2007) was followed by a new increment in Cladocera densities (Figure 6d).

Figure 7 shows the importance curves of Cladocera species obtained in the four examined situations. In December 2000 (at the end of the extreme drought period) and in July 2001 (seven months after lateral inundation of water by the Paranapanema River), assemblies were shaped by four and five species, respectively. The first curve shows high dominance of Ceriodaphnia cornuta rigaudi (897,657 individuals. $\left.\mathrm{m}^{-3}\right)$ and Diaphanosoma birgei (96,313 individuals. $\mathrm{m}^{-3}$ ). Concerning the second assembly (July 2001), the dominance degree was less accentuated, since densities of the two more abundant populations were 4,135 (for Bosminopsis deitersi) and 3,049 individuals. $\mathrm{m}^{-3}$ (Diaphanosoma birgei). During a hydrologic year with high waters (in April 2006), Cladocera assembly richness was shaped by 17 species, presenting densities ranging from 1,360 to 6 individuals.m ${ }^{-3}$. In November 2006, (low waters, during a period with loss of connectivity of the river with the lake, see Figure 2), the assembly involved 16 Cladocera populations, presenting densities ranging from 9,154 to 40 individuals. $\mathrm{m}^{-3}$. 


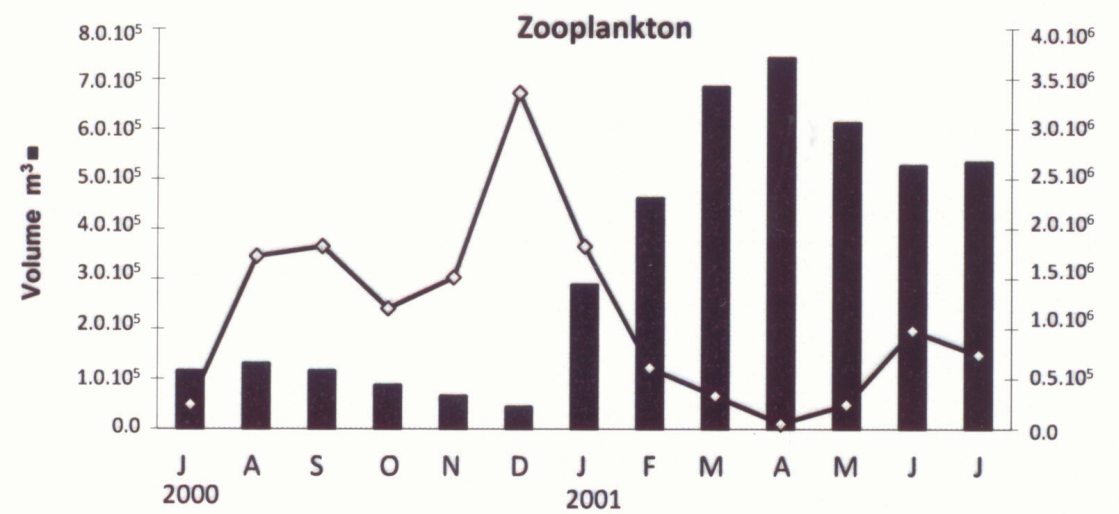

(a)

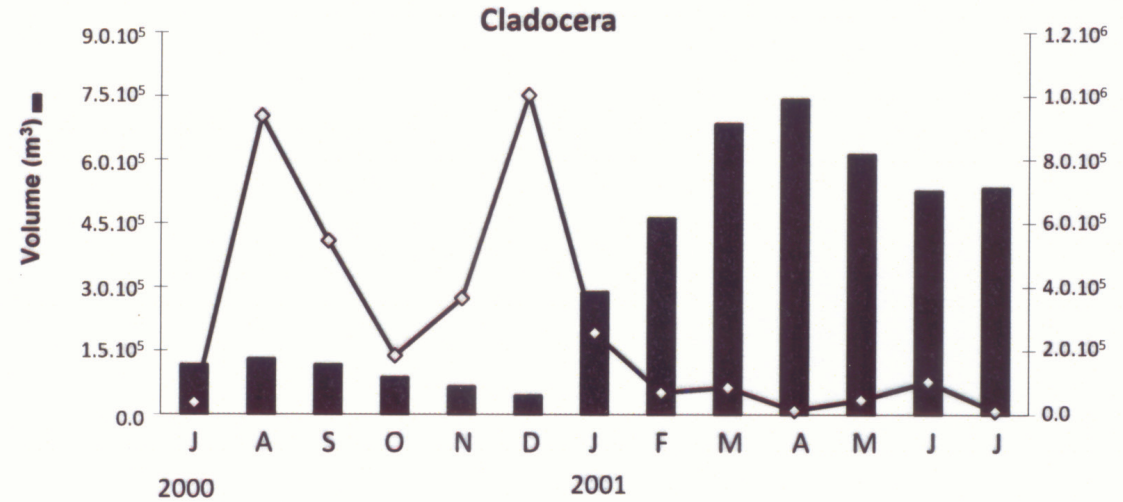

돌

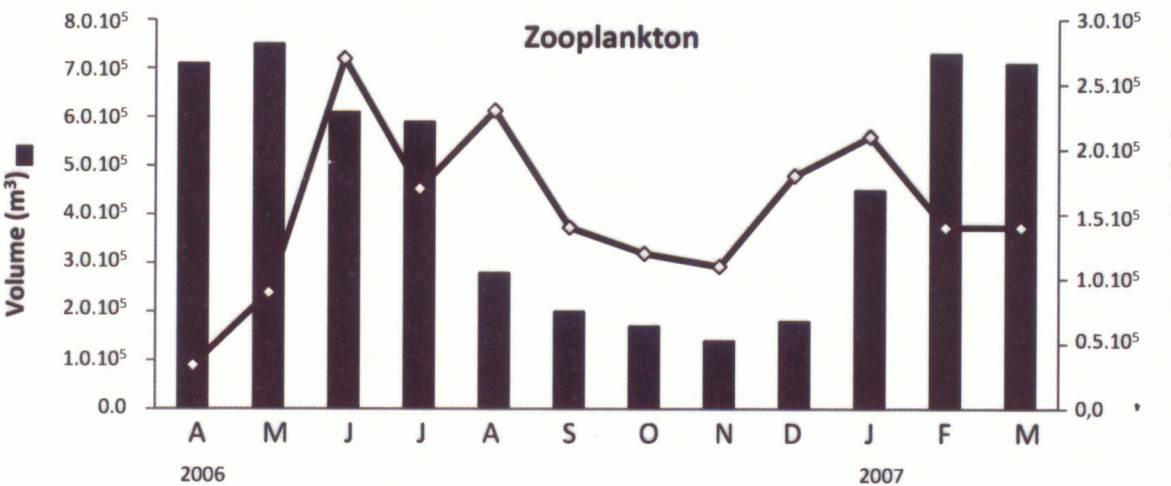

(c)

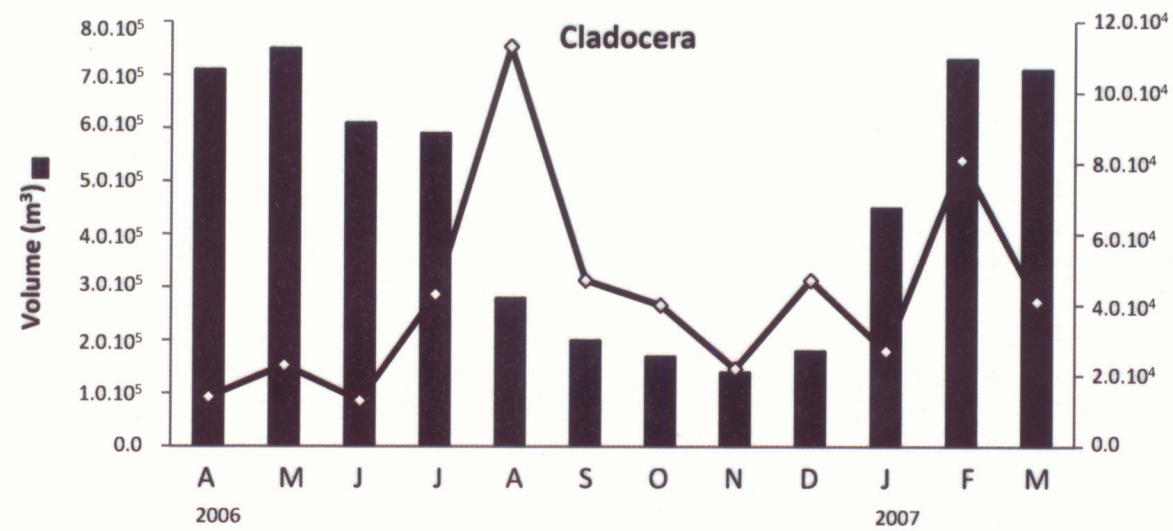

(d)

Figure 6. Monthly variations of volume in Camargo Lake (black bars) and total density of Zooplankton and Cladocera during and after the prolonged drought period (Figures a and b, respectively) and during the hydrologic years of 2006-2007 (Figures c and d, respectively). 

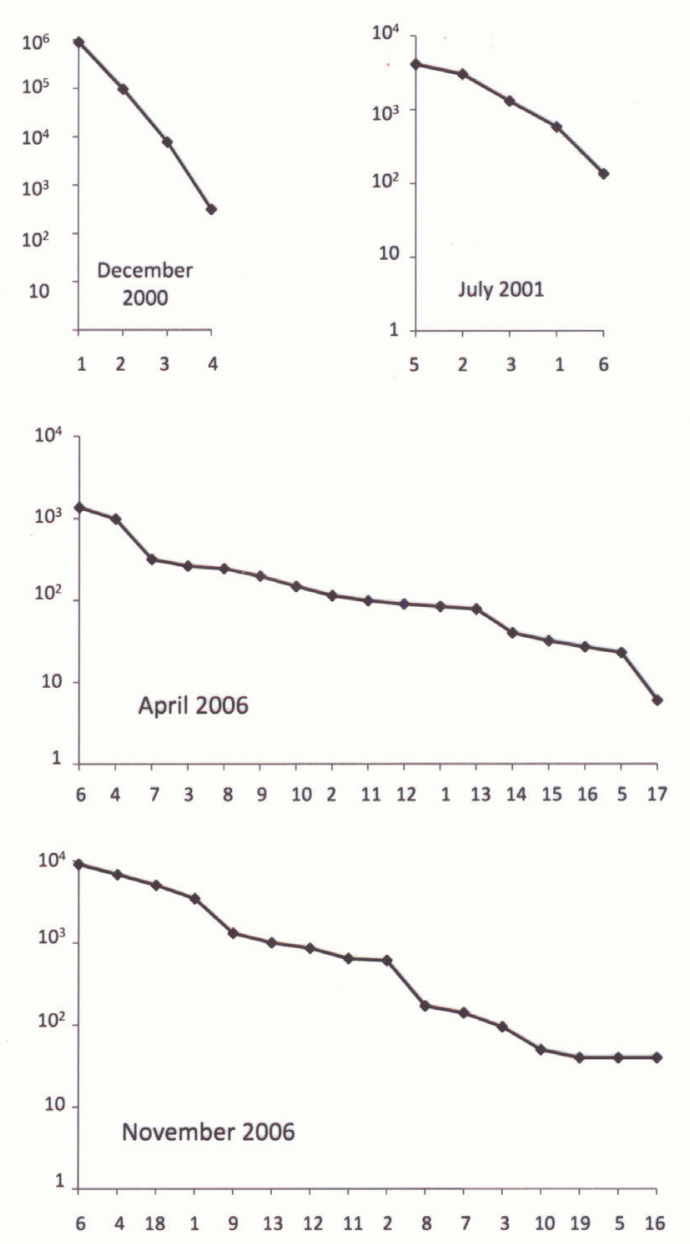

Figure 7. Importance curves of Cladocera populations in Camargo Lake at the end of the prolonged drought (December 2000) and seven months after the inundation (July 2001) and in high waters (April 2006) and disconnection periods (November 2006). (The numbers on the horizontal axis refer to decreasing order of importance and correspond to the following Cladocera species: 1- Ceriodaphnia cornuta rigaudi, 2- Diaphanosoma birgei; 3- Bosmina hagmanni, 4- Moina micrura, 5- Bosminopsis deitersi, 6- Moina minuta, 7- Ceriodaphnia cornuta cornuta, 8- Bosmina freyi, 9- Diaphanosoma fluviatile, 10- Daphnia ambigua; 11- Diaphanosoma brevireme; 12- Diaphanosoma spinulosum, 13- Ceriodaphnia cornuta intermedia, 14- Simocephalus serrulatus, 15Daphnia gessneri; 16- Ceriodaphnia silvestrii; 17- Kurzia polyspina; 18Ceriodaphnia sp.; 19- Bosmina tubicen).

\section{DISCUSSION}

THE PHYTOPLANKTON IN LACUSTRINE ENVIRONMENTS DURING THE PROLONGED DROUGHT PERIOD AND IN A SITUATION OF PERMANENT CONNECTIVITY WITH RIVER

The great algae species richness of the Paranapanema River, when compared with that of the lateral lakes, can be attributed to hydrologic instability resulting from high variability of the water current of the lotic ecosystem and current reduction due to water stored in the Jurumirim Reservoir (Henry 2003, Henry et al. 2006b). This condition determined high species diversity, except in February 2000, when (Chroomonas spp.) population predominated in the assembly (Henry et al. 2006a). Changes in current velocity of the river can bring species from litoral zones of the watercourse, modifying algae richness and abundance. Organisms of the Bacillariophyceae class were especially favored by river water turbulence, which maintains cells in suspension in depths where luminosity and nutritive conditions are more favorable to growth. During the prolonged drought, the unique lentic environment presenting a continuous reduction in richness was Coqueiral Lake, which, before the drought presented high hydrologic connectivity with the river. Isolation of Coqueiral Lake from a situation of potamophase to another of limnophase produced a reduction in species diversity indexes when compared with the situation in the Paranapanema River (Figure 4). In the other two lacustrine environments (Camargo Lake, an environment with minor hydrologic connectivity in the period prior to drought, and Cavalos Lake, an environment isolated from the river), annual variability in species number was low in comparison to Coqueiral Lake. No dominant algae specie was found in Cavalos Lake in the three sampling periods, and the diversity indexes presented higher values when compared with the other two lentic environments. Probably the lack of the hydrologic pulse effects by the Paranapanema River, due to connectivity loss, was the great determinant of low species diversities of phytoplankton in the two lakes (Coqueiral and Camargo), connected to the river in a situation prior to drought. In the inundation periods, an inverse relation between hydrologic level and phytoplanktonic population densities, a consequence of the dilution effect, is commonly observed in lakes connected with a river (Espíndola et al. 1996, Ibanez 1998, Melo \& Huszar 1998, Train \& Rodrigues 1998). In the prolonged drought episode, the lack of connectivity of the lakes with the river provoked an accentuated reduction in the volumes ten months later (see, for example, the case of Cavalos Lake, Figure 7) and in depths (Henry 2005). Cavalos Lake, an environment isolated from the river, was extinct ten months later 
(Panarelli et al. 2008). Despite the reduction in lake dimensions, no concentration effect on densities of algae populations was observed, except in May for Cavalos Lake, one month before extinction. Components of Cryptophyceae (Chroomonas spp. and Cryptomonas brasiliensis) and Chlorophyceae (Chlamydomonas spp.) predominated in the three lacustrine environments, and no significant alteration was observed with the progress of the drought (Henry et al. 2006a). These three species had the most abundant populations in diversified phytoplankton assemblies of lakes. Peculiar characteristics of lakes during the drought period, presenting dimensions in diminution, high light extinction, low transparency due to sediment re-suspension during windy episodes, and suitable nutritive conditions (in terms of total $\mathrm{N}$ and $\mathrm{P}$ concentrations) provided an important development of phytoflagellates (Henry et al. 2006a). The Cryptophyceae species, dominant during the study period, are "opportunistic" organisms and proliferate when the densities of the other algae decrease or after environmental disturbances (Klaveness 1988). These species are phagotrophes, tolerant to low luminosity, and usually found in rivers and small lakes (Isakssson 1998).

In a year of hydrologic connectivity of the Paranapanema River with the two connected lakes (Coqueiral and Camargo), sampling periods (August and November 2004, February, April, and May 2005) corresponded, respectively, to the end of inundation, drought, inundation, high water and falling periods (Granado et al. 2009). Despite the annual variation in the hydrologic level of $2.30 \mathrm{~m}$ (Figure 2), the lateral lakes maintained an association with river. Water current velocity of the river was low at the beginning of the drought and attained the maximum "peak" in the inundation period (Granado \& Henry 2008). Coqueiral and Camargo Lakes presented a similar seasonal variation pattern for the majority of water chemical and physical factors when compared with the Paranapanema River, evidencing the great level of association between both aquatic environments. However, in the isolated lentic environment (Cavalos Lake), all the values of measured variables (except $\mathrm{pH}$, suspended matter, and water transparency) were distinct from those of the other studied environments, evidencing that intra-lake processes are determinant for this variation pattern.
Compared with the situation of prolonged drought, species richness in the Paranapanema River was significantly lower (in all five samplings in each of three months) in a year of hydrologic connectivity. During the extreme drought, the river presented a hydrologic level lower than in other years (Figure 2 ), resulting in an agglomeration of algae species, while a dilution due to elevation of water level in the river in the connectivity period can determine a reduction in the number of recorded species. In the hydrologic connectivity period (August 2004 to June 2005), species richness in the river was higher than in the lacustrine environments, probably due to high instability (water flow, turbulence, and discharge) of the lotic ecosystem. A relevant fact is the record of high densities of algae populations in Cavalos Lake (an environment isolated from the river) in the months corresponding to inundation (February), high waters (April), and the beginning of the falling period (June). Another communication between the Paranapanema River and Cavalos Lake was detected through underground interactions between both aquatic systems, increasing the volume of the lake isolated from the river (Carmo 2007). The elevation in water level in Cavalos Lake determined a submersion of litoral vegetation, a degradation process began, and a reduction of dissolved oxygen and a eutrophy condition were produced. Suitable nutritive conditions and luminosity led to a great proliferation of phytoplankton, which was not observed in the other two lakes.

A similar pattern of variation in algae species diversity was found in the Paranapanema River and Coqueiral Lake (a lake with great connectivity with the river). Higher values were observed in emptying and low level in falling periods. Low diversity was recorded in the inundation period in Camargo Lake. In the lake isolated (Cavalos) from the river, a continuous increase in species diversity was detected in the four phases of the hydrologic cycle, and a drastic diminution occurred in the emptying period. In these two environments, it is likely that the high algae species diversity was related to the surface (Camargo Lake) and underground (Cavalos Lake) hydrologic pulse.

The constant presence and dominance of Cryptomonas brasiliensis in the several stages of the hydrologic cycle are probably related to their survival 
strategy, described as being that of an opportunistic organism (Granado et al. 2009). Peaks in its development were observed after disturbances, such as mixing by wind and rain episodes (Klaveness 1988). Disturbance caused by inundation (after river water level increase) appears to favor C. brasiliensis, the only organism with significant density in connected lakes during the inundation period (Granado \& Henry 2008). In other months, the development of this species can be related to wind and rain episodes some days before phytoplankton samplings. High nitrate and phosphate concentrations and low luminosity in water were observed (Granado \& Henry 2008) and, combination of both factors shapes suitable conditions for specie growth. In an isolated lake (Cavalos), the triggering factor for algae species growth is the underground water flux generated by the Paranapanema River at the beginning period of inundation.

\section{SPATIAL DISTRIBUTION OF ROTIFERA}

ASSEMBLY IN A LATERAL LAKE TO A RIVER

DURING A "FRAGMENTATION" PERIOD AND

IN A SITUATION OF ECOSYSTEM INTEGRITY

During the prolonged drought period, Coqueiral Lake disconnected from the Paranapanema River and fragmented into four water bodies isolated from each other as a result of bottom topography of the lacustrine environment (Henry 2005). These small water bodies presented significant spatial and temporal differences for the majority of measured environmental variables (Nadai \& Henry 2009). Spatially (comparison between the four water bodies), fragment " $B$ " (the nearest to the connection with the river) presented higher oxygen, total alkalinity, and chlorophyll-a concentrations than the others (Nadai \& Henry 2009). Both authors showed also that in fragment "A", an area isolated from the river, the lowest water transparency, $\mathrm{pH}$, conductivity and alkalinity, and highest depth were recorded. Temporally, depths of the four fragments presented low values in the drought period and increased after the re-connection of the lake with the river. Lowest transparencies were observed during the isolation period and increased after the lateral inflow of water from the Paranapanema River (Nadai $\&$ Henry 2009). Dissolved oxygen and $\mathrm{pH}$ diminished after the recovery of hydrologic connectivity with the river, as compared with the isolation period. Water-dissolved oxygen and $\mathrm{pH}$ decreased after the recovery of hydrologic connectivity with the river, as compared with the conditions during the period of isolation. Water conductivity and chlorophyll- $a$ tended to increase during the isolation period and decreased after the re-connection of the lake with the river. This brief description of water characteristics gives evidence of environmental distinction of the four water bodies which formed in the drought period and shows that, after an inundation, environmental homogeneity due to water influx in a lateral plain does not always occur, different from that reported in another paper (Thomas et al. 2007).

Reduction in size (area and volume) of the four "fragments" with the evolution of the drought significantly affected the Rotifera species richness, especially in July 2000. In the ninth month of isolation, the drastic diminution in depths caused sediment exposure in some sampling sites, reducing the colonization area and Rotifera richness, especially in areas " $\mathrm{B}$ " and " $\mathrm{D}$ ". The highest Rotifera richness in fragment " $A$ ", which was the most isolated from the river and presented the greatest depth in relation to the others, can be attributed to apparent environmental stability. In the isolation period of the lake, reduction in size of the four fragments with the progression of the drought caused a concentration effect in Rotifera densities, especially in fragments " $C$ " and " $D$ " (the latter at the end of drought).

Lateral inundation of the lake by the Paranapanema River at the end of December 2000 showed that the first consequence was an increase in Rotifera taxa richness in all four areas corresponding to the "fragments". Some factors may have contributed to the increment of Rotifera species in Coqueiral Lake. The first is an introduction of species present in river water, after the lateral influx. According to Henry (2003), surveys conducted prior to the drought period showed that Rotifera richness in the Paranapanema River is significantly higher than in the connected lentic environments. Also, Aoyagui \& Bonecker (2004) recorded higher Rotifera richness in connected lakes than in those isolated from the river in the floodplain of High Paraná, Brazil, which suggests that the high species number of Rotifera was related to the river. A second factor affecting the Rotifera richness in the pelagic zone of the four areas/fragments of Coqueiral 
Lake could be the washout of aquatic macrophytes after the recovery of hydrologic connectivity with the Paranapanema River. In fact, during the drought period and fragmentation of Coqueiral Lake, an increase in cover area by Eichhornia azurea was observed (Henry 2003). According to Afonso (2002), the amount of aquatic invertebrates associated with E. azurea increased during the high-water period. It is probable that removal of rotifers from the litoral zone could be the cause of an increase in richness in the pelagic zone of the lake. Another factor could be the rotifers' emergence from resistance eggs from exposed sediment on the edges of the four "fragments" after the lateral influx of water from the river (Panarelli et al. 2008). Albritton \& White (2004) showed higher numbers of Rotifera and other zooplankton species in a litoral zone of a reservoir in the USA that hatched from eggs of sediment in areas regularly submitted to drought and inundation rather than from areas continuously covered by water. Also, a high diversity of Rotifera species is due to availability of varied food resources, dissolved organic matter, and detritus which originated after the inundation by the river. Organisms from this group of zooplankton are detritus filterers and predominate immediately after inundation, as was also observed by Tavernini (2008) in temporary pools in a mountain zone of Italy. Despite the increase in species richness immediately after the connection of the lake with the river (in February 2001), rotifer densities in the four areas/fragments showed no increase in relation to the drought period.

In the hydrologic year of 2006, Coqueiral Lake maintained its integrity as a single system and, at the shallowest sites, rooted macrophytes emerged and allowed for delimitation of four distinct areas of the aquatic environment due to undulated bottom topography. In area "A", the lowest mean of suspended matter, highest temperature, transparency, and depth, in relation to the values of other areas, were observed (Abra 2008). However, no significant temporal difference in these factors was recorded. This area is an isolated site in relation to the Paranapanema River and suffers little variation in water levels; it presents an apparent hydrologic stability, with few windy episodes and without re-suspension of bottom material. Area " $\mathrm{B}$ " is characterized as presenting higher electrical conductivity, $\mathrm{pH}$, dissolved oxygen, and suspended matter during the year than the other areas of the lake (Abra 2008). Water quality in area " $B$ " is affected by hydrologic changes of the Paranapanema River in a peculiar position near the site of connection with the river. High annual means of total phosphorus and nitrogen and chlorophyll-a were reported for area "D", far from the connection with the river (Abra 2008).

Establishment of Rotifera non-planktonic and planktonic taxa indicates that different ecological niches occupied an open area presenting marginal vegetation in inundation and emptying periods (Bonecker et al. 1998). In the high-water period (April 2006), some Rotifera species are probably conveyed from marginal vegetation that exports typical species from litoral to limnetic zones. Elevation of fluvial level favored hydrologic connectivity intra-lake. In fact, the number of Rotifera species was higher in the high-water period, especially in areas " $A$ " (more isolated from the river) and " $\mathrm{D}$ " (far from the river). Reduction in Rotifera taxa number at the beginning of the emptying period (July) could be explained by apparent export of organisms from areas nearest the river (Areas "B", "C", and "D"). Species richness in the more isolated area (area "A") suffered little effect from the reduction of hydrologic level. In October 2006, Coqueiral Lake was in limnophase and beginning the formation of the four isolated water bodies. After the disruption of hydrologic connectivity with the Paranapanema River, the retraction of intra-lake water probably provoked a concentration effect, facilitating sampling of rare Rotifera species. An increase in population densities of rotifers in October, as compared with the other sampling periods, was also attributed to this effect. Doubling of Rotifera concentration in area "A" was quite evident, as compared with the beginning of the falling period.

Comparing the two studied years, a contrast can be seen. At the end of the extreme drought period (from April to October 2000), the Rotifera species mean richness was lower in the four areas than in the connection period of Coqueiral Lake with Paranapanema River. Hydrologic connectivity appears to favor the species increment in the prolonged drought, apparently due to the concentration effect, by reduction in volumes of areas/fragments. In the hydrologic connectivity period, population densities 
are at low levels and present low annual variability. When new isolation of lake from the river occurs, an increase in assembly density is produced.

ANNUAL VARIABILITY IN TOTAL DENSITY

OF ZOOPLANKTON ASSEMBLY AND

ESPECIALLY OF CLADOCERA ORGANISMS IN

A LATERAL LAKE. IMPORTANCE CURVES OF

POPULATIONS OF CLADOCERA SPECIES IN

SELECTED PERIODS

The studied lake (Camargo) presents higher variability in volume than in surface area, as shown in a monthly investigation of dimension modifications during a four-year period (Henry 2005). From the ninth month of disconnection from Paranapanema River (in July) up to the end of the prolonged drought, decreasing volume was observed. According to Panarelli (2004), three distinct phases could be identified in this period: 1) from July to August 2000, Camargo Lake showed a reduction in depth, slightly acid water $\mathrm{pH}$ and alkalinity, and a discrete increase in chlorophyll-a and suspended matter: 2) from October to December 2000 (end of prolonged drought period), decrease in depth, increase in $\mathrm{pH}$ (to basic range), alkalinity, suspended matter (predominantly organic fraction), conductivity and chlorophyll-a, nutritive conditions typical of the eutrophic stage with bloom presence of Cyanophyceae, probably from genus Anabaena or Pseudoanabaena spp.; 3) from February to July 2001, after the recovery of hydrologic connectivity with the river, water was characterized by a low amount of suspended matter, slightly acid $\mathrm{pH}$, increase in conductivity and decrease in chlorophyll-a. In the first phase (July and August), zooplankton and Cladocera total densities increased as a result of the lake volume, which had a concentration effect on the planktonic biota. A second peak of zooplankton increase and especially of Cladocera occurred in December, as a result of a combination of several factors: a concentration effect, by reduction in lake volume, and suitable nutritive and feeder conditions. After the recovery of hydrologic connectivity, the significant increase in lake volume provoked a drastic reduction in zooplankton densities, as well in Cladocera organisms, by a dilution effect, and in July attained similar levels to those observed in a period prior to the drought (Martins \& Henry 2004).
Thus, this observation is evidence that zooplankton assembly presented resilience after the occurrence of a severe disturbance (the prolonged 14-month duration drought).

A direct relationship between total density of zooplankton with the volume of Camargo Lake was evidenced in a year of short-term disconnection (around four months) from the river. A peak in density ( $95 \%$ of zooplankton, constituted by Rotifera, according to Mortari (2009)) was verified in June 2006 in the high-water period when the hydrologic levels were high (Figure 2). Continuous emptying of Camargo Lake initially determined (from August to November) a reduction in zooplankton total density (predominantly shaped by Copepoda, 58 and 38\% of total planktonic organisms in September and October, respectively, according to Mortari (2009)), which was the inverse of that in the drought period, when a concentration effect was detected. The low zooplanktonic population densities were affected by reduction in depths of the lentic environment, high turbidity by re-suspension of bottom material during windy episodes, and drastic extinction of light, diminishing the organic production (Mortari 2009). At the end of limnophase of the lake (December and January), a concentration effect was observed due to an increase in zooplankton densities, when the lake volume presented the lowest value. Intense rainfall in December 2006 and in January and February 2007 (Figure 3) determined the re-establishment of hydrologic connectivity after lateral inflow of water from the Paranapanema River (Figure 2). Thus, after the increase in lake volume, the diminution in zooplankton concentrations is evidence of a slight effect of dilution.

In the first months of annual study (from April 2006 to March 2007), the lowest Cladocera densities appeared to be due to various factors, such as horizontal lake $\rightarrow$ river migration, dilution effect due to the high volume of the lake, predation, and intra-specific competition (Arcifa et al. 1992, Lima et al. 1998, José de Paggi \& Paggi 2007). A peak in Cladocera was attained in August, at the beginning of the emptying period, when organisms predominated within zooplankton assembly ( $45 \%$ of total density). High abundance can be related to a concentration effect due to diminution of lake depths, an increase in water oxygenation, great reproductive capacity due 
to water temperature, and to the availability of food resources (Mortari 2009). In the period of Camargo Lake volume reduction, Cladocera density also showed a decrease in organism number. In this period (September to January), the lacustrine environment was in limnophase and presented a decreasing total volume. During windy episodes, fetch and predominant direction of wind (in a parallel of the maximum length of the lake, around $1 \mathrm{~km}$ ) determine a re-suspension of inorganic matter from the bottom, affecting the filtration process of Cladocera organisms and thus reducing densities of its populations. After the re-connection of the river with the lake (at the end of March), lateral introduction of water produces a dilution in turbidity and an increase in Cladocera populations.

Environmental stress (the prolonged drought) determined an assembly composed of a few Cladocera populations, two of them with high dominance. Even seven months after recovery of hydrologic connectivity of the Paranapanema River with Camargo Lake, and after the extreme drought period, Cladocera assembly increased by only one species, and the structure was typically of the predominance of few populations. Configuration of the structure of both these assemblies adjust to loglinear or Motomura model (Dajoz 2005, Ferreira \& Petrere 2008), characterized by intense competition between the species, a factor (the extreme drought/ recent inundation) that is determinant in the presence of few species. In December 2000, Camargo Lake was in a limnophase of long duration (14 months), with extremely low depths and volume, high turbidity, algae species restricted to opportunistic cryptophycean phagotrophs resistant to low luminosity, limiting the diet of filtering cladocerans. In July 2001, Camargo Lake was an environment probably still in hydrologic instability, after being submitted to a long isolation from the Paranapanema River. Five years later (2006), the lake was in a prolonged potamophase, without disruption of connection with the river since 2002 (see Figure 2), thus in a stable hydrological situation. Cladocera assembly in the high-water period (April 2006) was compounded by a great number of species, but with low variability in its densities. Even after the beginning of loss of hydrologic connectivity with the river (November 2006), the assembly structure was similar to that before the high-water period. Both adjusted to the Preston log-normal model (Dajoz 2005, Ferreira \& Petrere 2008), in which all species utilize available resources from the environment, and regulating factors of population abundance involve water characteristics acting in combination.

\section{SYNTHESIS: A VIEW ON FUNCTIONING OF LENTIC ENVIRONMENTS LATERAL TO TRIBUTARIES IN THE MOUTH ZONE INTO RESERVOIRS - A LESSON FROM PLANKTON DYNAMICS}

Is hydrologic connectivity the only factor controlling the dynamics of plankton? In the limnophase period, factors internal to lakes are determinant in the control of population dynamics and in ecological processes, such as organic matter production and decomposition, while during the potamophase, factors external to lakes have a predominant role (Thomaz et al. 1997, Henry et al. 2006b). Lateral influx of water from the river after the recovery of surface hydrologic connectivity with lentic lateral environments has as an effect an increase in planktonic species richness due to washout of macrophytes, to introduction of the species allochthonous to lakes by conveyance through the watercourse, and to the hatching of resistance eggs in inundated sediment. According to Thomaz et al. (2007), after the inundation pulse, the water quality of lateral environments presents similar characteristics. Study of spatial and temporal distribution of a Rotifera assembly in a fractioned lentic environment and in a period of integrity as an ecosystem indicates that this view can be an over-simplification. In fact, water and biota characteristics showed a variation as a function of the distance from the main channel of the river and the isolation degree of the examined intra-lake areas. Thus, intra-lake spatial heterogeneity, due to dependence on bottom topography and the presence of emergent macrophytes, was of fundamental importance in the internal distribution of planktonic populations and in the variability of controlling abiotic factors

Dynamics of plankton population densities in lateral lacustrine environments appears to be controlled indirectly by the hydrologic pulse of the river. Lateral inundation introduces a variable amount of water that immediately provokes a dilution effect, 
increasing transparency and luminosity. However, the elevation of river level causes submersion of the vegetation present in areas with exposed sediment during the limnophase, determining a reduction in water oxygen due to decomposition and thus a regeneration of water-dissolvable inorganic nutrients. Only after these conditions can plankton increase numerically. During the limnophase, a recurrent process is a concentration effect on plankton densities and a decrease in species richness. With the continuous reduction in lake volume, the wind action determines sediment re-suspension from the bottom, causing severe extinction of luminosity and constituting the main limiting factor of algae growth.

In the lentic environment isolated from the river, the underground hydrologic connectivity appears to be a relevant regulatory factor. In drought period, the underground water influx from lake to river contributes to determining a concentration effect on lentic environment. In high-water period, the underground water influx from river to lake determines a slow elevation in depth of the lentic environment, submersing plants of the litoral zone, and the degradation generates a high oxygen biochemical demand and nutritive conditions suitable for the growth of planktonic organisms.

Hydrologic dynamics and its influence on planktonic assembly, described in this study, are affected by climatological variations, but also by the buffer effect of the operation of the Jurumirim hydroelectric plant, which controls the water discharge. According to Collinschoon et al. (2005), traditional management of water flux has as a main aim the reduction of the natural variability of river discharge in order to offer water for diverse uses and to prevent extreme situations of prolonged high waters and drought. Richter et al. (2003) said that ecological degradation and its effect on water quality had usually been an undesirable consequence of management of river discharge due to a lack of understanding of the dynamics of discharge necessary to preserve the quality of aquatic ecosystems. Knowledge of the influence of inundation pulses in the dynamics of planktonic populations in the mouth zone of tributaries into reservoirs can be important to make decisions for a better management of water discharge and guarantee economic necessities and other water uses in the short term, but also for the recovery of ecological integrity of damming systems in the medium and long term.

ACKNOWLEDGEMENTS: The first author, Raoul Henry is grateful to FAPESP (Proc. 97/04999-7) for the financial support during the first four years of the study and to FUNDIBIO in the years following. Eliana A.Panarelli (Proc. 99/08748-5), Danielli C.Granado (Proc. 03/124739), and Juliana Abra (Proc. 06/54280-0) acknowledge FAPESP for the scholarships. Rafael C.Mortari and Silvia M.C. Casanova received a scholarship from CAPES and CNPq (Proc. 141360/2000-3), respectively. The authors are also grateful to Hamilton Antonio Rodrigues and Lucio Miguel de Oliveira for the help in field and laboratory work, to Juliana Ramos for the figure preparation and to Laerte José da Silva, for the English revision of the manuscript.

\section{REFERENCES}

ABRA, J. 2008. Variação sazonal da composição, abundância e diversidade de rotíferos na Lagoa do Coqueiral, lateral ao Rio Paranapanema em sua zona de desembocadura na Represa de Jurumirim, SP. Dissertação de Mestrado. Universidade Estadual Paulista. Instituto de Biociências de Botucatu, Botucatu, SP, Brasil. 88p.

AFONSO, A.A.O. 2002. Relações da fauna associada à Eichhornia azurea (Swartz) Kunth com as variáveis abióticas em lagoas laterais de diferentes graus de conexão ao Rio Paranapanema (zona de desembocadura na Represa de Jurumirim, SP). Tese de Doutorado. Universidade Estadual Paulista. Instituto de Biociências de Botucatu. Botucatu, SP, Brasil. 99p.

AGOstinHO, A.A.; PELICICE, F.M. \& GOMES, L.C. 2008. Dams and the fish fauna of the Neotropical region: impacts and management related to diversity and fisheries. Brazilian Journal of Biology, 68: 1119-1132.

ALBRITTON, C.J. \& WHITE, D.S. 2004. Hatching of rotifer eggs from reservoir sediment. Southeastern Naturalist, 3: 359370 .

AMERICAN PUBLIC HEALTH ASSOCIATION (APHA). 1995.

Standard methods for the examination of water and wastewater. $19^{\text {th }}$ ed., Byrd Prepess Spingfield, Washington, DC. 1155p.

ANAGNOSTIDIS, K. \& KOMAREK, J. 1988. Modern approach to the classification system of Cyanophytes, 3: Oscillatoriales. Algological Studies, 50: 327-472.

AOYAGUI, A.S.M. \& BONECKER, C.C. 2004. Rotifers in different environments of the Upper Paraná River floodplain (Brazil): richness, abundance and the relationship with connectivity. Hydrobiologia, 522: 281-290. 
ARCIFA, M.S., GOMES, E.A.T. \& MESCHIATTI, A.J.C. 1992. Composition and fluctuations of the zooplankton of a tropical Brazilian reservoir. Archives fur Hydrobiologie, 123: 479-495.

BONECKER, C.C.; LANSAC-TOHA, F.A. \& ROSSA, D.C. 1998. Planktonic and nonplanktonic rotifers in two environments of the Upper Paraná River floodplain, State of Mato Grosso do Sul, Brazil. Brazilian Archives of Biology and Technology, 41: 447-456.

BONECKER, C.C.; AOYAGUI, A.S.M. \& SANTOS, R.M. 2009. The impact of impoundment on the rotifer communities in two tropical floodplain environments: inter-annual pulse variations. Brazilian Journal of Biology, 69: 529-537.

BORNETTE, G.; AMOROS, C. \& LAMOUROUX, N. 1998. Aquatic plant diversity in riverine wetlands: the role of connectivity. Freshwater Biology, 39: 267-283.

BOURRELLY, P. 1981. Les algues d'eau douce: initiation à la systématique: les algues jaunes et brunes, les Chrysophycées, Phéophycées, Xanthophycées et Diatomées. Éditions N. Boubée, Paris, IF. 517p.

BOURRELLY, P. 1985. Les algues d'eau douce: initiation à la systématique: les algues bleues et rouges, les Eugléniens, Péridiniens, et Cryptomonadines. Éditions N. Boubée, Paris, IF. 509 .

BRANDLOVA, J.; BRANDL, Z. \& FERNANDO, C.H. 1972. Cladocera of Ontário with remarks on some species and distribution. Canadian Journal of Zoology, 50: 1373-1403.

CARMO, C.F. do. 2007. Influência do aquífero freático na dinâmica de nutrientes (nitrogênio e fósforo) em lagoas com diferentes características hidrodinâmicas. Tese de Doutorado. Universidade de São Paulo. Escola de Engenharia de São Carlos. São Carlos, SP, Brasil. 257p.

CASANOVA, S.M.C \& HENRY, R. 2004. Longitudinal distribution of Copepoda populations in the transition zone of Paranapanema River and Jurumirim Reservoir (São Paulo) and interchange between two lateral lakes. Brazilian Journal of Biology, 64: 11-26.

COLLISCHOON， W.; SOUZA， C.F.; FREITAS， G.K.; PRIANTE, G.R.; AGRA, S.G. \& TASSI, R. 2005. Em busca do hidrograma ecológico. Pp. 421-453. In: J.N. Campos (Org.). Recursos Hídricos: Jovem Pesquisador 2005. ABRH, Fortaleza, CE. 526p.
DAJOZ, R. 2005. Principios de Ecologia. Tradução de Fátima Murard. Artmed Editora, Porto Alegre, RS. 520p.

EDMONDSON, W.T. 1959. Freshwater biology. Second Edition. John Wiley \& Sons, London, GL. 1248p.

ELMOOR-LOUREIRO, L.M.A. 1997. Manual de identificação de cladóceros límnicos do Brasil. Editora Universia, Brasília, DF. $156 \mathrm{p}$.

ESPÍNDOLA, E.G.; MATSUMURA-TUNDISI, T. \& MORENO, I.D. 1996. Estrutura da comunidade fitoplanctônica da Lagoa Albuquerque (Pantanal Mato-grossense). Acta Limnologica Brasiliensia, 8: 13-27.

FERREIRA, F.C \& PETRERE-Jr., M. 2008. Comment about some species abundance patterns: classic, neutral and partionning models. Brazilian Journal of Biology, 68: 1003-1012.

GALAT, D.L.; KUBISIAK, J.F.; HOOKER, J.B. \& SOWA, L.W. 1997. Geomorphology, distribution and connectivity of lower Missouri River floodplain waterbodies scoured by the flood of 1993. Verhandlungen der Internationalen Vereinigung fur Theoretische und Angewandte Limnologie, 26: 869-878.

GRANADO, D.C. \& HENRY, R. 2008. The influence of the hydrologic pulse on the water physical and chemical variables of lateral lakes with different connection levels to Paranapanema River in the mouth zone at Jurumirim Reservoir (São Paulo, Brazil). Acta Limnologica Brasiliensia, 20: 265-275.

GRANADO, D.C.; HENRY, R. \& TUCCI, A. 2009. Influência da variação do nível hidrométrico na comunidade fitoplanctônica do Rio Paranapanema e de uma lagoa marginal na zona de desembocadura na Represa de Jurumirim (SP). Hoehnea, 36: 113-129.

HAMILTON, S.K.; SOUZA, O.C. \& COUTINHO, M.E. 1998. Dynamics of floodplain inundation in the alluvial fan of the Taquari River (Pantanal, Brazil). Verhandlungen der Internationalen Vereinigung fur Theoretische und Angewandte Limnologie, 26: 916-922.

HENRY, R. 2003. Os ecótonos nas interfaces dos ecossistemas aquáticos: conceitos, tipos, processos e importância. Estudo de aplicação em lagoas marginais ao Rio Paranapanema na zona de sua desembocadura na Represa de Jurumirim. Pp. 1-28. In: R. Henry (org.). Ecótonos nas interfaces dos ecossistemas aquáticos. RiMa Editora, São Carlos, SP. 349p. 
HENRY, R. 2005. The connectivity of the Paranapanema River with two lateral lakes in its mouth zone into Jurumirim Reservoir. Acta Limnologica Brasiliensia, 17: 57-69.

HENRY, R. 2009. Annual changes in sediment entrapment efficiency in lakes lateral to a river (Paranapanema river, São Paulo, Brazil). Acta Limnologica Brasiliensia, 21: 25-34.

HENRY, R. \& MARICATO, F.E. 1996. Sedimentation rates of tripton in Jurumirim Reservoir (São Paulo, Brazil). Limnologica, 26: $15-25$.

HENRY, R.; PANARELLI, E.A.; CASANOVA, S.M.C.; SUIBERTO, M.R. \& AFONSO, A.A.O. 2006a. Interações hidrológicas entre lagoas marginais e o Rio Paranapanema na zona de sua desembocadura na Represa de Jurumirim. Pp. 57-82. In: M.G. Nogueira, R. Henry \& A. Jorcin (orgs.). Ecologia de Reservatórios: impactos potenciais, ações de manejo e sistemas em cascata. Rima Editora, São Carlos, SP. 459p.

HENRY, R.; USHINOHAMA, E. \& FERREIRA, R.M.R. 2006b. Fitoplâncton em três lagoas marginais ao Rio Paranapanema e em sua desembocadura no Reservatório de Jurumirim (São Paulo, Brasil) durante um período prolongado de seca. Revista Brasileira de Botânica, 29: 399-414.

HUSZAR, V.L.M. \& REYNOLDS, C.S. 1997. Phytoplankton periodicity and sequences of dominance in a Amazonian floodplain lake (Lago Batata, Pará, Brazil): responses to gradual environmental change. Hydrobiologia, 346: 169-181.

IBANEZ, M.S.R. 1998. Phytoplankton composition and abundance of a central Amazonian floodplain lake. Hydrobiologia, 362: 79-83.

ISAKSSON, A. 1998. Phagotrophic phytoflagellates in lakes - a review. Archives fur Hydrobiologie Special Issues Advances in Limnology, 51: 63-9.

JOSÉ DE PAGGI, S. \& PAGGI, J.C. 2007. Zooplankton. Pp. 229-249. In: M.H. Iriondo, J.C. Paggi \& M.J. Parma (Eds.). The middle Paraná River: Limnology of a Subtropical Wetland. Springer-Verlag, Berlin, BL. 382p.

JUNK, W.J.; BAYLEY, P.B. \& SPARKS, R.E. 1989. The flood pulse concept in river-floodplain systems. Canadian Special Publication on Fisheries and Aquatic Sciences, 106: 110-127.

KLAVENESS, D. 1988. Ecology of the Cryptomonadina: a first review. Pp. 105-133. In: C.D. Sandgren (ed.). Growth and reproductive strategies of freshwater phytoplankton. Cambridge University Press, Cambridge, CB. 442p.
KOMAREK, J. \& ANAGNOSTIDIS, K. 1998. Cyanoprokariota. 1. Teil Chroococcales. Pp. 1-548. In: H. Ettl, G.Gartner, H. Heynig \& D. Mollenhauer (eds.). Subwasserflora von Mittleeuropa. Gustav Fischer Verlag, Stuttgart, BW. 876p.

KOMAREK, J. \& ANAGNOSTIDIS, K. 2005. Cyanoprokariota. 2. Teil Oscillatoriales. Pp.1-759. In: B. Budel, L. Krienitz, G. Gartner \& M. Schagerl (eds.). Subwasserflora von Mittleeuropa. Elsevier: Spektrum Akademischer Verlag, Munique, BA. 759p.

KOROVCHINSKY, M.M. 1992. Guides to identification of the microinvertebrates Sididae \& Holopeidae (Crustacea:Daphniiformes). SPB Academic Publishing, The Hague, TH. 42p.

KOSTE, W. 1978. Rotatorie: die radertiere mitteleuropas. Vol. I \& II. Text Band. Bebrudea Borntraeger, Berlin, BL. 237p.

KREBS, C.J. 1972. Ecology: The experimental analysis of distribution and abundance. Harper \& Row Publishers, New York, NY. 694p.

KRUSCHE, A.V. \& MOZETO, A.A. 1999. Seasonal variations in water quality of an oxbow lake in response to multiple shorttime pulses of flooding (Jataí Ecological Station Mogi-Guaçu River, Luiz Antonio, SP-Brazil). Anais da Academia Brasileira de Ciências, 71: 777-790.

LAMBERTI, G.A.; CHALONER, D.T. \& HERSHEY, A.E. 2010. Linkages among aquatic ecoystems. Journal of North American Benthological Society, 29: 245-263.

LANSAC-TÔHA, F.A.; BONECKER, C.C.; VELHO, L.F.M.; SIMÕES, N.R.; DIAS, J.D.; ALVES, G.M. \& TAKAHASHI, E.M. 2009. Biodiversity of zooplankton communities in the Upper Paraná River floodplain: interannual variation from longterm studies. Brazilian Journal of Biology, 69: 539-549.

LIMA, A.F.; LANSAC-TOHA, F.A.; VELHO, L.F.M. \& BINI, L.M. 1998. Environmental influence on planktonic cladocerans and copepods in the floodplain of the upper river Paraná, Brazil. Studies on Neotropical Fauna \& Environments, 33: 188-196.

MARGALEF, R. 1983. Limnologia. Omega, Barcelona, CT. $1010 \mathrm{p}$.

MARTINS, G.M. \& HENRY, R. 2004. Composição e abundância do zooplâncton em três lagoas laterais ao Rio Paranapanema na zona de sua desembocadura na Represa de Jurumirim (São Paulo). Pp. 53-72. In: N. T. Chellappa, B. Chellappa. \& J.Z.O. Passavante (eds.). Ecologia tropical aquática. ServGraf, Natal, RN. 165 p. 
MELO, S. \& HUSZAR, V.L.M. 1998. Phytoplankton in an Amazonian floodplain lake (Lake Batata, Brasil): diel variation and species strategies. Journal of Plankton Research, 22: 63-76.

MORTARI, R.C. 2009. Distribuição espaço-temporal de Cladocera (Crustacea, Branchiopoda) em uma lagoa subtropical lateral ao Rio Paranapanema (zona de desembocadura na Represa de Jurumirim/SP). Tese de Doutorado. Universidade Estadual Paulista. Instituto de Biociências de Botucatu. Botucatu, SP, Brasil. 172p.

NADAI, R. \& HENRY, R. 2009. Temporary fragmentation of a marginal lake and its effects on zooplankton community structure and organization. Brazilian Journal of Biology, 69: 819-835.

NEIFF, J.J. 1999. El regimen de pulsos en rios y grandes humedales de Sudamérica. Pp. 97-145. In: A.I. Malvarez. \& P. Kandus (eds.). Tópicos sobre grandes humedales sudamericanos. Orcyt-MAB (UNESCO), Ed. Univers. de Buenos Aires, Buenos Aires, BA. 224p.

NEIFF, J.J. \& POI de NEIFF, A.S.G. 2003. Connectivity processes as a basis for the management of aquatic plants. Pp. 39-58. In: S.M. Thomaz \& L.M. Bini (eds.). Ecologia e Manejo de Macrófitas Aquáticas. Editora da UEM, Maringá, PR. 341p.

NOGRADY, T.E. \& SEGERS, H. 2002. Rotifera. Volume 6: Asplanchnidae, Gastropodidae, Lindiidae, Microcodidae, Synchaetidae, Trochosphaeridae and Filinia. Backhuys Publisher, Leiden, HS. 264p.

NOGUEIRA,M.G.; FERRAREZE，M.; MOREIRA，M.L. \& GOUVEA, R.M. 2010. Phytoplankton assemblages in a reservoir cascade of a large tropical-subtropical river (SE, Brazil). Brazilian Journal of Biology, 70: 781-793.

OLIVEIRA, M.D. de \& CALHEIROS, D.F. 2000. Flood pulse influence on phytoplankton communities of the south Pantanal floodplain, Brazil. Hydrobiologia, 427: 101-112.

PANARELLI, E.A. 2004. Flutuações mensais da comunidade zooplanctônica e dinâmica das populações de Cladocera em lagoas marginais, na região de transição Rio Paranapanema Represa de Jurumirim (SP). Tese de Doutorado. Universidade Estadual Paulista. Instituto de Biociências de Botucatu. Botucatu, SP, Brasil. 247p.

PANARELLI, E.A.; CASANOVA, S.M.C. \& HENRY, R. 2008. The role of resting eggs in the recovery of zooplankton community in a marginal lake of the Paranapanema River (São Paulo, Brazil), after a long drought period. Acta Limnologica Brasiliensia, 20: 73-88.
PHILIPS, E.J.; HAVENS, K.E. \& LOPES, M.R.M. 2008. Seasonal dynamics of phytoplankton in two Amazon flood plain lakes of varying hydrologic connectivity to the main river channel. Fundamental and Applied Limnology, 172: 99-109.

POMPEO, M.L.M.; HENRY, R. \& MOSCHINI-CARLOS, V. 1999. Ecologia de Echinochloa polystachya do Rio Paranapanema - SP, Brasil. Pp. 737-767. In: R. Henry (ed.). Ecologia de reservatórios: estrutura, função e aspectos sociais. FAPESP, FUNDIBIO, Botucatu, SP. 799p.

PONTIN, R.M. 1978. Freshwater planktonic and semi-planktonic Rotifera of the British Isles. Freshwater Biological Association Scientific Publication, Ambleside, CM. 178p.

REID, J.W. 1985. Chave de identificação e lista de referências bibliográficas para as espécies continentais sulamericanas de vida livre da ordem Cyclopoida (Crustacea, Copepoda). Boletim de Zoologia, 9: 17-143.

RICHTER, B.; MATHEWS, R.; HARRISON, D.L. \& WIGINGTON, R. 2003. Ecologically sustainable water management: Managing river flows for ecological integrity. Ecological Applications, 13: 206-224.

ROBERTO, M.C.; SANTANA, N.F. \& THOMAZ, S.M. 2009. Limnology in the Upper Paraná River floodplain: large-scale spatial and temporal patterns, and the influence of reservoirs. Brazilian Journal of Biology, 69: 717-725.

ROCHA, O. \& MATSUMURA-TUNDISI, T. 1976. Atlas do zooplâncton (Represa do Broa, São Carlos) Vol. I - Copepoda. Centro de Ciências e Tecnologia, Departamento de Ciências Biológicas, Universidade Federal de São Carlos. São Carlos, SP, Brasil. 68p.

ROUND, F.E. 1971. The taxonomy of the Chlorophyta II. British Phycological Journal, 6: 235-264.

SEGERS, H. 1995. Rotifera. Volume 2: The Lecanidae (Monogononta). SBP Academic Publishing. The Hague, TH. $224 \mathrm{p}$.

SHELDON, F.; BOULTON, A.J. \& PUCKRIDGE, J.T. 2002. Conservation value of variable connectivity: aquatic invertebrate assemblages of channel and floodplain habitats of a central Australian arid-zone river, Cooper Creek. Biological Conservation, 103: 13-31.

SIMONSEN, R. 1979. The diatom system: ideas on phylogeny. Bacillaria, 2: 9-71. 
TAVERNINI, S. 2008. Seasonal and inter-annual zooplankton dynamics in temporary pools with different hydroperiods. Limnologica, 38: 63-75.

THOMAZ, S.M.; ROBERTO, M.C. \& BINI, L.M. 1997. Fatores limnológicos abióticos e clorofila-a: caracterização dos habitats e influências do pulso de inundação. Pp. 73-102. In: A.E.A.M. Vazzoler, A.A. Agostinho \& N.S. Hahn (eds.). A planície de inundação do alto rio Paraná: aspectos físicos, químicos, biológicos e socioeconômicos. EDUEM, Maringá, PR. 460p.

THOMAZ, S.M.; BINI, L.M. \& BOZELLI, R.L. 2007. Floods increase similarity among aquatic habitats in river-floodplain systems. Hydrobiologia, 579: 1-13.

TOCKNER, K.; MALARD, F. \& J.V. WARD. 2000. An extension of flood pulse concept. Hydrological Processes, 14: 2861-2883.

TRAIN, S. \& RODRIGUES, L.C. 1998. Temporal fluctuations of the phytoplankton community of the Baia River, in the Upper Paraná River floodplain, Mato Grosso do Sul, Brazil. Hydrobiologia, 361: 125-134.

UTERMOHL, H. 1958. Zur vervollkommung der quantitativen phytoplankton-methodic. Verhandlungen der Internationalen Vereinigung fur Theoretische und Angewandte Limnologie, 9: 1-38.

VAN DEN BRINK, F.W.B.; VAN KATWIJK, M.M. \& VAN DER VELDE, G. 1994. Impact of hydrology on phyto- and zooplankton community composition in floodplain lakes along the Lower Rhine and Meuse. Journal of Plankton Research, 16: 351-373.

WARD, J.V.; TOCKNER, K. \& SCHIEMER, F. 1999. Biodiversity of floodplain river ecosystems: ecotones and connectivity. Regulated Rivers: Research and Management, 15: 125-139.

Submetido em 20/02/2011 Aceito em 18/07/2011 